http://journal.uinsgd.ac.id/index.php/biodjati

\title{
EFFECT OF FERMENTED KANGKONG SEED (Ipomoea reptans Poir.) ON CHARACTERISTICS AND HISTOLOGY OF FEMALE QUAIL REPRODUCTIVE ORGANS
}

\section{Astuti Kusumorini ${ }^{1 *}$, Rachmat Wiradimadja ${ }^{2}$, Ramadhani Eka Putra ${ }^{3}$, Ana Rochana ${ }^{4}$, Denny Rusmana ${ }^{5}$}

Received : April 20, 2020

Accepted : April 11, 2021

DOI: 10.15575/biodjati.v6i1.8295

1,2,4,5 Faculty of Animal Science, Universitas Padjajaran, Jl. Bandung - Sumedang KM. 21, Jatinangor, Sumedang 45363, West Java, Indonesia ${ }^{1}$ Department of Biology, Faculty of Science and Technology, UIN Sunan Gunung Djati Bandung, Jl. A.H. Nasution No. 105, Cibiru, Bandung 40614, West Java, Indonesia

${ }^{3}$ School of Life Sciences and Technology, Institut Teknologi Bandung Labtex XI SITH-ITB , Jl. Ganesa 10, Bandung 40132, West Java, Indonesia.

e-mail:

*1astuti16001@mail.unpad.ac.id

rachmatwr@gmail.com

ramadhaniputra@gmail.com

aaaochana@gmail.com

5ndennyrusmana@unpad.ac.id

*Corresponding author
Abstract. Quail has a high reproductive ability, which can reach three to four generations a year. The quail also have high eggs productivity and capable of producing 250-300 eggs/quail/year. Egg production is closely related to the reproductive system and feed. It is necessary to know the effect of feeding fermented kangkong on the characteristics and histology of the quail reproductive organs. The increase in livestock population should be balanced with an increase in the availability of feed. Kangkong seeds waste (Ipomoea reptans Poir.) is rejected seeds from seed factories that have the potential to become alternative feed ingredients because it contains about $13.46 \%$ protein. The purpose of this study was to determine the effect of fermented kangkong seed feed (Bikafer) on the characteristics of reproductive tract organs and histology of quail oviducts because feeds affect the development of the reproductive tract and quail egg production. This study used a completely randomized design method (CRD) with 5 treatments and 4 replications. The treatments were as follows: $R 0=$ commercial feed, $R 1=0 \%$ (Bikafer), $R 2=7.5 \%$ (Bikafer), $R 3=$ $15 \%$ (Bikafer), $R 4=22.5 \%$ (Bikafer). Data were analyzed using one-way ANOVA with a significance level of $95 \%(\alpha=0.05)$ and the Kruskal-Wallis test, while histological observations were described descriptively. The results showed that there were significant differences in the characteristics of the uterus, vaginal length, and isthmus weights. The histology of the quail reproductive tract developed well and showed the tunica mucosal tissue, serous tunica, muscular tunica, goblet cells, epithelium, and tubular gland cells.

Keywords: feed, fermentation, histology, kangkong seeds (Ipomoea reptans Poir.), quail (Coturnix-coturnix japonica), reproductive organs,

\section{Citation}

Kusumorini, A., Wiradimadja, R., Putra, R. E., Rochana, A. \& Rusmana, D. (2020). Effect of Fermented Kangkong Seed (Ipomoea reptans Poir.) on Characteristics and Histology of Female Quail Reproductive Organs. Jurnal Biodjati, 6(1), 111-121.

\section{INTRODUCTION}

One of the most important macromolecules of humans is protein. The human re- quirement for protein mostly fulfilled by the consumption of farm animals. Among those animals, poultry had been considered as the most important source of animal protein for 


\section{JURNAL BIDDJATI}

http://journal.uinsgd.ac.id/index.php/biodjati

humans. In general, products of domesticated chicken are the most common source of protein. However, in some regions, quail have been gaining more popularity as an alternative source of protein.

Compare to chicken, quail has a short life cycle, high reproductive and adaptability, low maintenance costs, and has a good immune system. Furthermore, due to their small body size, it can be placed in a multilevel cage and does not require a large area (Vali, 2008). In general, there is a positive trend in quail product (eggs and meat) consumption in the world (Ramteke et al., 2013).

Like other poultry, feed significantly affects the productivity of the biomass production and total cost of the production (as up to $70 \%$ of the production cost required for feed purchasing). In many regions, ingredients as sources of the energy (i.e. corn) and protein (i.e. fish mill) of the feed still rely on imports and this condition reduces the sustainability of the production due to fluctuation of the exchange rate. To improve the sustainability of production, it is necessary to find alternative sources of energy and protein for the feed which available in large numbers, not utilize as part of human food, and low cost, such as waste products of biobased industries. One of the industries that produce a large quantity of waste is agriculture-related industries. However, most agricultural wastes characterized by their high crude fiber content but low protein content which made it impractical for poultry feed. The application of fermentation technology may increase the nutritional value and reduce the crude fiber of these wastes (Laelasari \& Purwadaria, 2004; Winarno, 2013; Sugiharto \& Samir, 2019).

The feed is an important factor to support livestock production. Corn and fish are still the main sources of energy and protein. These materials are still consumed by hu- mans. The search for poultry feed ingredients needs to be increased, such as using agricultural by-product which has a nutritional value equal to or better than commercial feed. Kangkong seeds are a waste that has not been used, but it still contains sufficient nutrients as poultry feed. Kangkong seeds contain $13.46 \%$ of with high fiber. Kangkong seed wastes are cheap and widely available. Its quality needs to be improved through the fermentation process. The fermentation process is one way to increase the nutrition of feed ingredients, reduce fiber, and eliminate anti-nutritional compounds.

In this study, fermented kangkong seed (we called Bikafer) was evaluated as a possible waste product to be applied as one of the ingredients of quail feed. Kangkong seed waste is a by-product of the seed producer industry. The study showed kangkong seed contains $13.46 \%$ crude protein and $16 \%$ crude fiber (Laboratorium makanan ternak UNPAD, 2017) and the nutrition quality was improved after fermentation (Kusumorini, unpublished data). The study focused on the effect of Bikafer on the feed to reproductive organs both physically, anatomically, and histologically as the reproductive organs are directly involved in egg formation which is one of the main economic products of quail.

\section{MATERIALS AND METHODS}

\section{Study Location and Quail Cage Profile}

The research was carried out at the Science and Technology Garden and the Animal Physiology Laboratory of UIN Sunan Gunung Djati Bandung from January to June 2019. The quails were kept inside multilevel wire cages equipped with feed containers, drinking water containers, incandescent lighting, and a thermometer-hygrometer to measure temperature and humidity. 


\section{JURNAL BIDDJATI}

http://journal.uinsgd.ac.id/index.php/biodjati

\section{Kangkong Seed Fermentation Process}

Kangkong seeds were fermented by 0.3 gram Rhizopus oligosporus per 100 grams seeds. The material was then moistened and dried at room temperature then kept inside a plastic bag with small holes on its surface. The fermentation process was carried out for 3 days ( 72 hours) at room temperature until the fungus fully covers the seeds. The resulting fermented products, called Bikafer, were then dried by basked in the sun for a few days. Dried bikafer was then ground to powder form to be mixed with other other feed ingredients.

\section{Research Design}

The study used a completely randomized design (CRD) with 5 treatments and 4 replications with 4 quails for each replication. The feed treatments used were commercial feed as a control (R0) and research feed formulation (R1-R4) which contains different amounts of Bikafer namely R1=0\% Bikafer, $\mathrm{R} 2=7.5 \%$ Bikafer, $\mathrm{R} 3=15 \%$ Bikafer, $\mathrm{R} 4=$ $22.5 \%$ Bikafer. The preparation of feed was carried out using standard nutrient composition based on SNI (2006) and NRC (1994) (Table 1).

Table 1. Feed formulation based on quail feed guidelines (SNI, 2006)

\begin{tabular}{lcccc}
\hline \multicolumn{1}{c}{ Feed ingredients } & $\mathrm{R} 1$ & $\mathrm{R} 2$ & $\mathrm{R} 3$ & $\mathrm{R} 4$ \\
\hline Corn meal & 35.94 & 35.94 & 35.94 & 35.94 \\
Soybean meal & 18.5 & 18.5 & 18.5 & 18.5 \\
Fish meal & 15.5 & 15.5 & 15.5 & 15.5 \\
Coconut cake & 11.8 & 7.8 & 3.9 & 0 \\
Ricebran cake & 10.7 & 7.2 & 3.6 & 0 \\
Bikafer & 0 & 7.5 & 15 & 22.5 \\
Coconut oil & 4.5 & 4.5 & 4.5 & 4.5 \\
Lysine & 0 & 0 & 0 & 0 \\
CaCO3 & 0.9 & 0.9 & 0.9 & 0.9 \\
Topmix & 0.5 & 0.5 & 0.5 & 0.5 \\
DCP/T. Tlng & 1.5 & 1.5 & 1.5 & 1.5 \\
Methionine & 0.16 & 0.16 & 0.16 & 0.16 \\
NaCl & 0 & 0 & 0 & 0 \\
\hline & 100 & 100 & 100 & 100 \\
\hline EM (kkal/kg) & 2897 & 2929 & 2961 & 2993 \\
CP (\%) & 24 & 24 & 24 & 24 \\
Ca (\%) & 1.16 & 1.17 & 1.18 & 1.19 \\
\hline Non-phytate P (\%) & 0.60 & 0.59 & 0.58 & 0.57 \\
\hline
\end{tabular}

\section{Feed Trial}

In this study, 80 7-day-old quails were acclimated for 7 days ( 5 treatments and 4 replications with 4 quails for each replication). Quails were fed with designated feed until they reached 55 days old (when they have matured sexually). Quails were given about 8 to 22 grams fed per day (according to age) and water was provided ad-libitum.

Jurnal Biodjati 6(1):111-121, May 2021

\section{Morphometric Measurements}

Quails were slaughter and the observation of the reproductive organs was conducted. The weights of reproductive organs were recorded in grams ( $\mathrm{g}$ ) using the electronic digital balance while the length and the external diameter of the sample were measured in centimeters $(\mathrm{cm})$ using ruler, thread, and vernier calipers. Variables observed were the length, 


\section{JURNAL BIDDJATI}

http://journal.uinsgd.ac.id/index.php/biodjati

weight, and width of ovaries, follicles, infundibulum, magnum, isthmus, uterus, and vagina as well as the histological appearance of magnum, isthmus, and uterus.

\section{Histological Study}

Prior observation and measurement of the reproductive organs, the organs were fixed by soaking in $10 \%$ formalin solution for 24 hours to prevent cells and tissues damaged followed by dehydration of the organs by immersing it in multilevel alcohol. The dehydrated tissues were then fixed by filling the extracellular area with paraffin the tissues were sectioned using a rotary microtome. The sections were floated in a water bath at $45^{\circ} \mathrm{C}$ and transferred to a glass slide to be stained. The histological slides were studied using a digital biological microscope at 40×, 100×,
$400 \times$ magnifications, and relevant photomicrographs of the various sections were taken.

\section{Data Analysis}

The data were statistically analyzed by One-Way ANOVA at a 95\% confidence level $(\alpha=0.05)$ with the Duncan test as a post hoc test by using SPSS. Histological data were observed descriptively.

\section{RESULTS AND DISCUSSION}

\section{Anatomy of the Reproductive Tract}

There was no anatomy change after consumption of Bikafer which indicated that this material did not cause a negative effect on the anatomy of the reproductive organ of the quail (Figure 1).

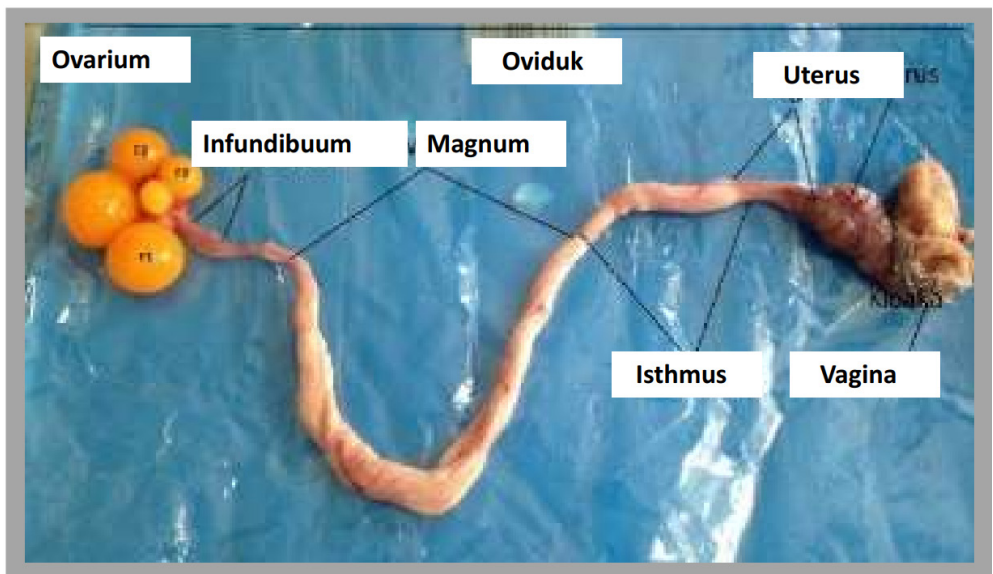

Figure 1. Morphology of quail reproductive tract after fed with Bikafer

The result indicated that Bifaker produced healthy and good oviduct development which important factor for initiation of egg formation (Renema et al., 2001), and dark brown uterus may produce a better egg pigmentation (Artoni et al., 2003). Anatomy observation also showed a good reproductive tract maturity which may play a significant role in good quality egg production (Robinson et al., 2001; Gongruttananun, 2011) along with weight (McDaniel et al., 1981).

Kusumorini et al.

\section{Biometric data of the female reproductive tract of the Japanese quail}

In general, the application of Bikafer did not significantly change the biometric of most of the reproductive organs of quail except for isthmus weight, uterus length, and vagina length which showed a reduction along with an increasing proportion of the Bikafer in their feed. 


\section{JURNAL BIDDJATI}

http://journal.uinsgd.ac.id/index.php/biodjati

Table 2. Average length, weight and width of infundibulum, magnum, isthmus, uterus, and vagina as well as ovarian weights, follicular weights and F1 diameter in quails treated with fermented kangkong seed meal (Bikafer).

\begin{tabular}{|c|c|c|c|c|c|c|}
\hline \multirow{2}{*}{ Variables } & \multicolumn{5}{|c|}{ Treatment } & \multirow{2}{*}{ P-Value } \\
\hline & R0 & $\mathrm{R} 1$ & $\mathrm{R} 2$ & R3 & $\mathrm{R} 4$ & \\
\hline Ovary Weight (g) & 7 & 6.5 & 8.5 & 6 & 7.5 & 0.113 \\
\hline Follicle Width $(\mathrm{cm})$ & 1.4 & 1.4 & 1.32 & 1.36 & 1.33 & 0.776 \\
\hline Infundibulum Length (cm) & 3.72 & 3.17 & 3.76 & 3.69 & 3.17 & 0.347 \\
\hline Infundibulum Width (cm) & 0.24 & 0.36 & 0.43 & 0.31 & 0.41 & 0.391 \\
\hline Infundibulum Weight (g) & 0.2 & 0.2 & 0.2 & 0.2 & 0.2 & 0.180 \\
\hline Magnum Length (cm) & 10.97 & 9.3 & 9.16 & 9.77 & 11.15 & 0.351 \\
\hline Magnum Width (cm) & 0.73 & 0.9 & 0.52 & 0.59 & 0.5 & 0.707 \\
\hline Magnum Weight (g) & 2.8 & 3.1 & 3.25 & 2.85 & 2.85 & 0.387 \\
\hline Isthmus Lenght (cm) & 4.88 & 3.34 & 4.31 & 4.85 & 3.91 & 0.64 \\
\hline Isthmus Width (cm) & 0.51 & 0.66 & 0.61 & 0.49 & 0.41 & 0.341 \\
\hline Isthmus Weight (g) & 0.65 & 0.65 & 0.7 & 0.8 & 0.55 & $0.015^{*}$ \\
\hline Uterus Length $(\mathrm{cm})$ & 4.25 & 3.79 & 4 & 4.85 & 3.91 & $0.022 *$ \\
\hline Uterus Width $(\mathrm{cm})$ & 1.48 & 1.84 & 1.46 & 1.22 & 1.20 & 0.413 \\
\hline Uterus Weight (g) & 1.5 & 1.4 & 1.7 & 1.6 & 1.35 & 0.696 \\
\hline Vagina Lenght $(\mathrm{cm})$ & 2.1 & 2.18 & 2.59 & 2.31 & 1.76 & $0.013^{*}$ \\
\hline Vagina Width (cm) & 0.51 & 0.66 & 0.64 & 1.11 & 0.89 & 0.741 \\
\hline Vagina Weight (g) & 0.7 & 0.65 & 1.00 & 1.2 & 0.7 & 0.322 \\
\hline
\end{tabular}

$\mathrm{R} 0=$ commercial feed; $\mathrm{R} 1=0 \%$ Bikafer; R2 $=7.5 \%$ Bikafer; R3 $=15 \%$ Bikafer and R4 $=22.5 \%$ Bikafer Note: $\mathrm{P}<0.05$ is significant, * (significant).

\section{Ovaries and Follicles}

The application of Bikafer as feed material did not significantly affect the ovarian weight as well as the weight and width of follicular produced by quail. Studies showed that both ovary and follicles, in poultry, are highly influenced by the amount of the protein ingested which affect the production of several hormones related to the development of both structures (Gilbert et al., 1983; Moreng \& Avens, 1985; Panjaitan et al., 2012; Abdul, 2016). The result thus indicated that the quality of Bifaker (in terms of the ingested protein) were similar to commercial feed and showed high potency as an alternative protein source for quail fed. Therefore the application of Bifaker probably will not reduce the egg production level and quality of the eggs as both highly influenced by the state of the ovary and follicles (Rose, 1997).

Egg production in poultry depends on the rate at which follicles mature and develop in the ovaries. Follicle development depends on the availability of nutrients, especially the deposition of the yolk component into the follicle (Yoshida et al., 2011). Poultry consumes feed to meet energy needs and protein which is used for growth and egg production (Ferket \& Gernat, 2006). Furthermore, consumption of nutrients will affect the availability of nutrients for follicular development and egg formation which will affect the performance of egg production (de Moura et al., 2010). Egg yolk precursors are synthesized in the liver and then sent to the follicle through the blood (Etches, 1996). Ovarian weights ranged from $6-8.5$ grams and were not affected by nutritional content or feed given. Compared 


\section{JURNAL BIDDJATI}

http://journal.uinsgd.ac.id/index.php/biodjati

to Saraswati et al. (2013) and Ratrianto et al. (2018) who stated that the weight of quail ovaries ranged from 3.5 - 6.3 grams and 5.545.66 grams.

The infundibulum acts as an organ that receives the ovum during ovulation and where fertilization occurs. The application of Bikafer as part of the feed ingredient did not affect the infundibulum, although the width of the organ from the quail fed with bikafer slightly bigger compared to the control group. Similar results also showed on the quails fed with seaweed (Horchow, 2012) which indicated the level of protein content may not play an important part in the development of this organ. The results of the study by Thakur \& Kapadnis (2019) showed the average length and diameter of the infundibulum increased from $3.34 \mathrm{~cm}$ and $0.177 \mathrm{~mm}$ to $3.5 \mathrm{~cm}$ and $0.35 \mathrm{~mm}$ in treated quail.

\section{Magnum}

Magnum is part of the reproductive tract that secretes the majority of 40 types of protein. The application of Bikafer did not affect the biometric of magnum although it slightly reduced the length (except for the R4 group) and width (except for the R1 group). The magnum length and diameter of the quail ranged between 9.16-11.50 and 0.5-0.9 cm respectively, the results were not much different from Majama et al. (2016) that observed the means of magnum length was $11.69 \mathrm{~cm}$ with an average diameter of $0.56 \mathrm{~cm}$. Meanwhile, Fitzgerald (1969) and Johnson (1986) reported a slightly taller magnum length of $13 \mathrm{~cm}$. These differences in observations may be due to environmental conditions, physiological levels, and species.

\section{Isthmus}

Isthmus is a narrow channel that connects two large channels that play a role in forming the first calcium carbonate crystal in the outer skin membrane, forming about $20 \%$ of the shell membrane (Brionne et al., 2014). The application of Bikafer significantly reduced the weight of the isthmus (Table 2). The average diameter and length of the isthmus respectively were 4.25 and 0.54 , while the results obtained by Majama et al. (2016) were 4.18 and 0.33 for isthmus length and its diameter.

\section{Uterus}

The uterus secretes large amounts of calcium and bicarbonate to protect eggshells and to provide a shell matrix protein that controls mineralization in the acellular environment (Brionne et al., 2014). The results showed the length of the uterus was varied and there was a significant difference in each treatment, the average length of the uterus was $4.16 \mathrm{~cm}$ with a diameter of $1.44 \mathrm{~cm}$. The value of uterus length and its diameter was higher when compared to Majama et al. (2016), namely $3.94 \mathrm{~cm}$ and $1.19 \mathrm{~cm}$ respectively.

The length of the uterus depends on the gonadotropin and estrogen (Prambudi, 2006; Satyaningtijas et al., 2016). Studies showed that the level of estrogen may be influenced by phytoestrogen (like isoflavones and glycosides), a substrate produced by plants that have estrogen-like activity. (Yildiz, 2005; Glover \& Assinder, 2006; Ravindran et al., 2007). The mechanism of action of isoflavones as phytoestrogens is that isoflavones can bind to estrogen receptors as part of hormonal activity, causing reactions that benefit the body (Arum et al., 2017). Rhizopus has different $\beta$-glucosidase enzyme activity. Hydrolysis with $\beta$-glucosidase enzymes can convert glycoside isoflavones into aglycone and glucose isoflavones (Purwoko et al., 2001). 


\section{JURNAL BIDDJATI}

http://journal.uinsgd.ac.id/index.php/biodjati

\section{Length, Width, and Weight of Vagina}

The vagina is the last channel of the oviduct and has no role in egg formation. The vagina is composed of muscles that function to push eggs out of the body of birds. This study showed the significant effect of the application of Bikafer to the length of the vagina as the increasing ratio of Bikafer in feed increased the length (except for the highest ratio) (Table 2). The length of the vagina is influenced by the estrogen hormone, produced by the ovaries, and oxytocin, produced by the posterior pituitary gland. The addition of Bikafer to the feed affected the length of the vagina with an average of $2.18 \mathrm{~cm}$, it is greater when compared to Majama et al. (2016) $1.34 \mathrm{~cm}$.

\section{Histology of Female Quail Reproductive Organs Fed with Bikafer}

The development of the quail reproductive tract is controlled by steroid sex hormones namely (1) Estrogen (E) which induces cell proliferation, tubular gland formation by epithelial cell evagination, and cell differentiation and Progesterone $(\mathrm{P})$ that inhibit cell proliferation, cell evagination, and differentiation of ciliated cells. The balance between $\mathrm{E}$ and $\mathrm{P}$ plays an important for the development of the quail reproductive tract (Perche et al., 1989).

Change in the feeding regime may change the rate of cell development then furtherly the shape and biometric of organs of the reproductive tract. However, in this study, we found, in general, that the application of Bifaker did not significantly affect the cell growth of the reproductive tract. This finding showed the possibility of the application of Bifaker as an alternative source of protein and energy for quail.

\section{Histological Appearance of Magnum}

Quail received Bikafer feed treatment showed high primary folds with a tighter arrangement (Figure 2). This condition could be caused by the isoflavones component of Bikafer, a common product of the fermentation process by Rhizopus oligosporus. Isoflavones have a chemical structure similar to estrogen (Bule et al., 2020). Higher estrogen content may enhance the production of cells of the mucosa of the magnum (Saraswati, 2016).

\section{Histological Appearance of Isthmus}

Isthmus of the quails fed with commercial feed (R0) has many columnar epithelium cells located intermittently with secretory cells while isthmus of the quails fed with Bikafer showed wider primary and secondary folds with deeper invagination, secondary folds are also seen more, stroma develops into tubular glands (Figure 3).

\section{Histological Appearance of Uterus}

The uterus of quails fed commercial feed treatment (R0) showed ciliated epithelium cells and secretory cells arranged intermittently to form a pseudostratified layer. On the other hand, the uterus of quails fed with Bikafer showed the composition of the ciliated epithelium cells and longer secretory cells while the tubular glands develop properly, with a dilated lumen (Figure 4).

However, when compared between treatments there were no significant differences in the histological appearance of each organ. This means that ration with Bikafer with various growth continues at a constant rate of mineralization (about $300 \mathrm{mg}$ of levels, has the same impact as the control or commercial feed.

Taken together, the present study showed that giving fermented kangkong seeds affected 
Jurnal Biodjati 6(1):111-121, May 2021

\section{JURNAL BIDDJATI}

http://journal.uinsgd.ac.id/index.php/biodjati

the length of the uterus, vaginal length, and weight of the isthmus. Histological observations on the reproductive organs of quail fed with Bikafer showed a well-developed cell. Thus it can be concluded that Bikafer can be used as an alternative feed for poultry.

Table 3. The presence of cells in the histological appearance of the Japanese quail reproductive tract fed by fermented kangkong seed (Bikafer).

\begin{tabular}{cccccccccccccc}
\hline Treatment & \multicolumn{3}{c}{ Magnum } & \multicolumn{1}{c}{ Isthmus } & \multicolumn{4}{c}{ Uterus } \\
\hline & MF & SE & GB & TG & MF & SE & GB & TG & MF & SE & GB & TG \\
\hline R0 & ++ & + & + & ++ & ++ & ++ & ++ & ++ & +++ & +++ & ++ & ++ \\
R1 & ++ & + & + & ++ & ++ & ++ & ++ & ++ & +++ & +++ & ++ & ++ \\
R2 & ++ & + & + & ++ & ++ & ++ & ++ & ++ & +++ & +++ & ++ & ++ \\
R3 & ++ & + & + & ++ & ++ & ++ & ++ & ++ & +++ & +++ & ++ & ++ \\
R4 & ++ & + & + & ++ & ++ & ++ & ++ & ++ & +++ & +++ & ++ & ++ \\
\hline
\end{tabular}

-: not develop; +: poorly develop; ++ : develop; $\geq+++$ : well develop. $\mathrm{R} 0=$ commercial feed; $\mathrm{R} 1=0 \%$ Bikafer; R2=7.5\% Bikafer; R3= 15\% Bikafer and R4= 22.5\% Bikafer. MF= Mucosal fold; SE $=$ secretory epithelium; $\mathrm{GB}=$ goblet cell; $\mathrm{TG}=$ tubular gland
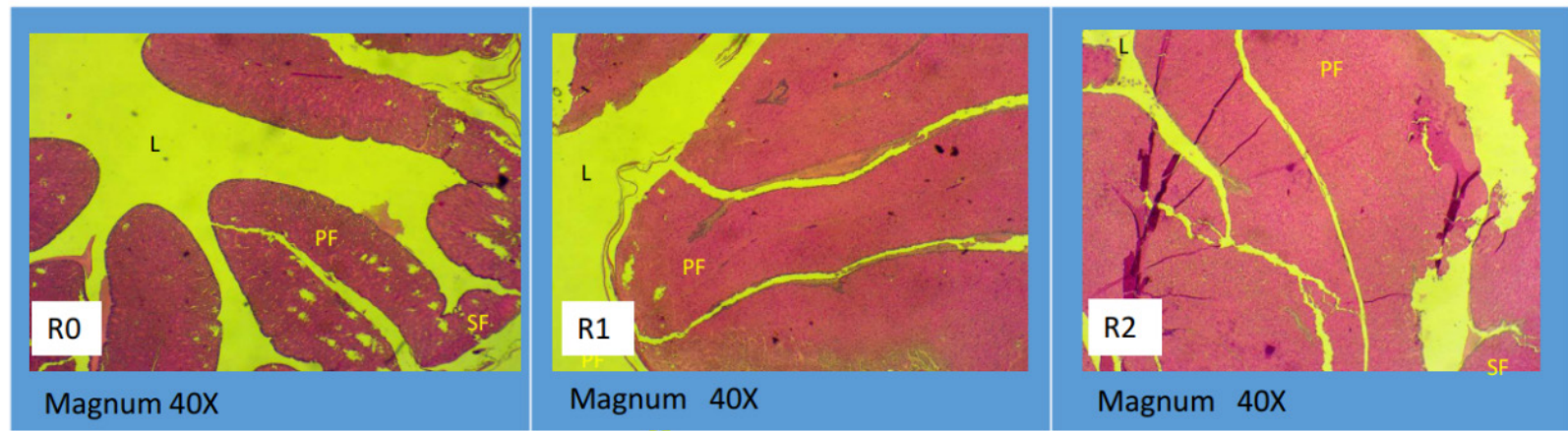

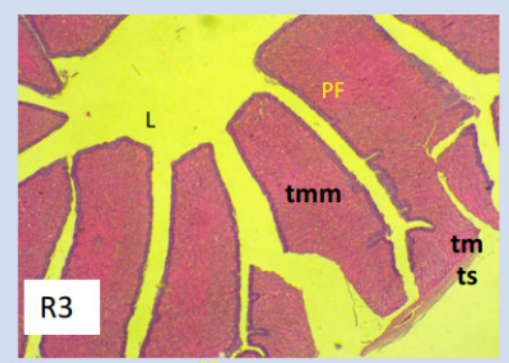

Magnum $40 \mathrm{X}$

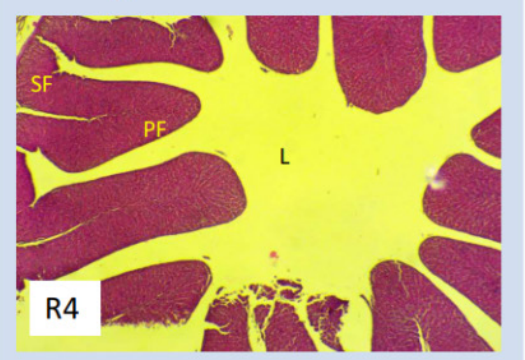

Magnum 40X

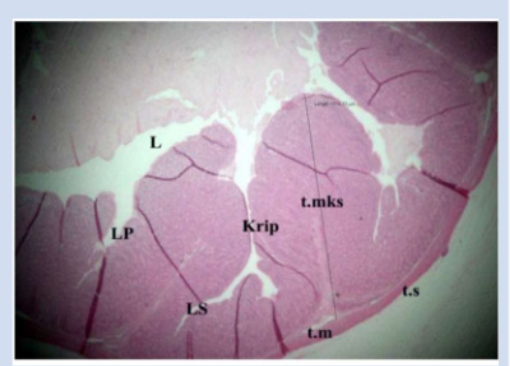

Magnum 40X ; Saraswati, 2016

Figure 2. Histology of Magnum in quail fed fermented kangkong seed meal (Bikafer). R0= commercial feed; R1= $0 \%$ Bikafer; R2 $=7.5 \%$ Bikafer; R3 $=15 \%$ Bikafer and R4 $=22.5 \%$ Bikafer. Magnification 40 $\times$ L: Lumen; PF: Primary Fold / Primary Fold; SF: Secondary Fold; tm: tunica mucosa; ts: tunica serosa; tmks: tunica muscularis 
Jurnal Biodjati 6(1):111-121, May 2021

\section{JURNAL BIDDJATI}

http://journal.uinsgd.ac.id/index.php/biodjati
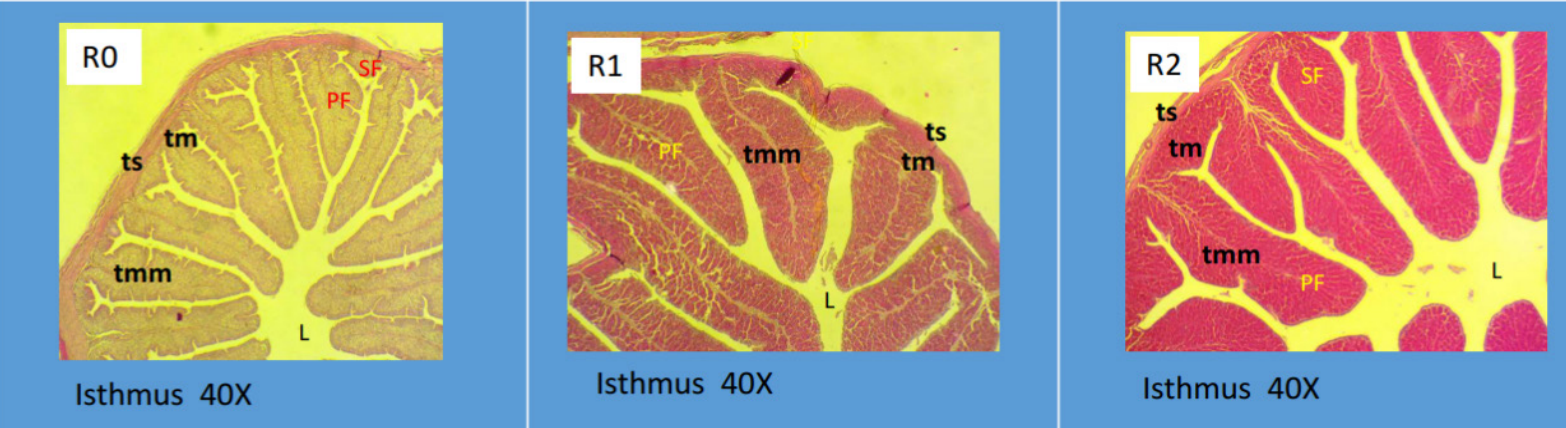

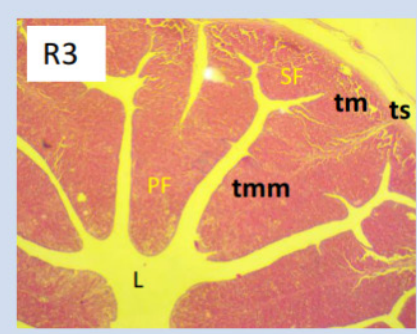

Isthmus $40 \mathrm{X}$

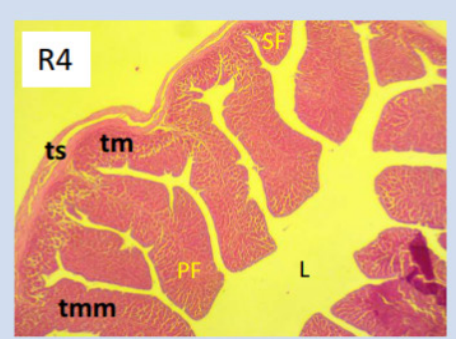

Isthmus $40 \mathrm{X}$

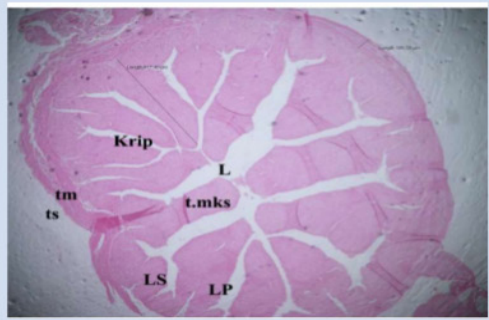

Isthmus 40X ; Saraswati, 2016

Figure 3. Histology of Isthmus in quail fed fermented kangkong seed meal (Bikafer). R0= commercial feed; $\mathrm{R} 1=0 \%$ Bikafer; R2 $=7.5 \%$ Bikafer; R3= 15\% Bikafer and R4 $=22.5 \%$ Bikafer. Magnification 40×. L: Lumen; PF: Primary Fold / Primary Fold; SF: Secondary Fold; tm:tunica mucosa; ts:tunica serosa; tmm: tunica muscularis mucos
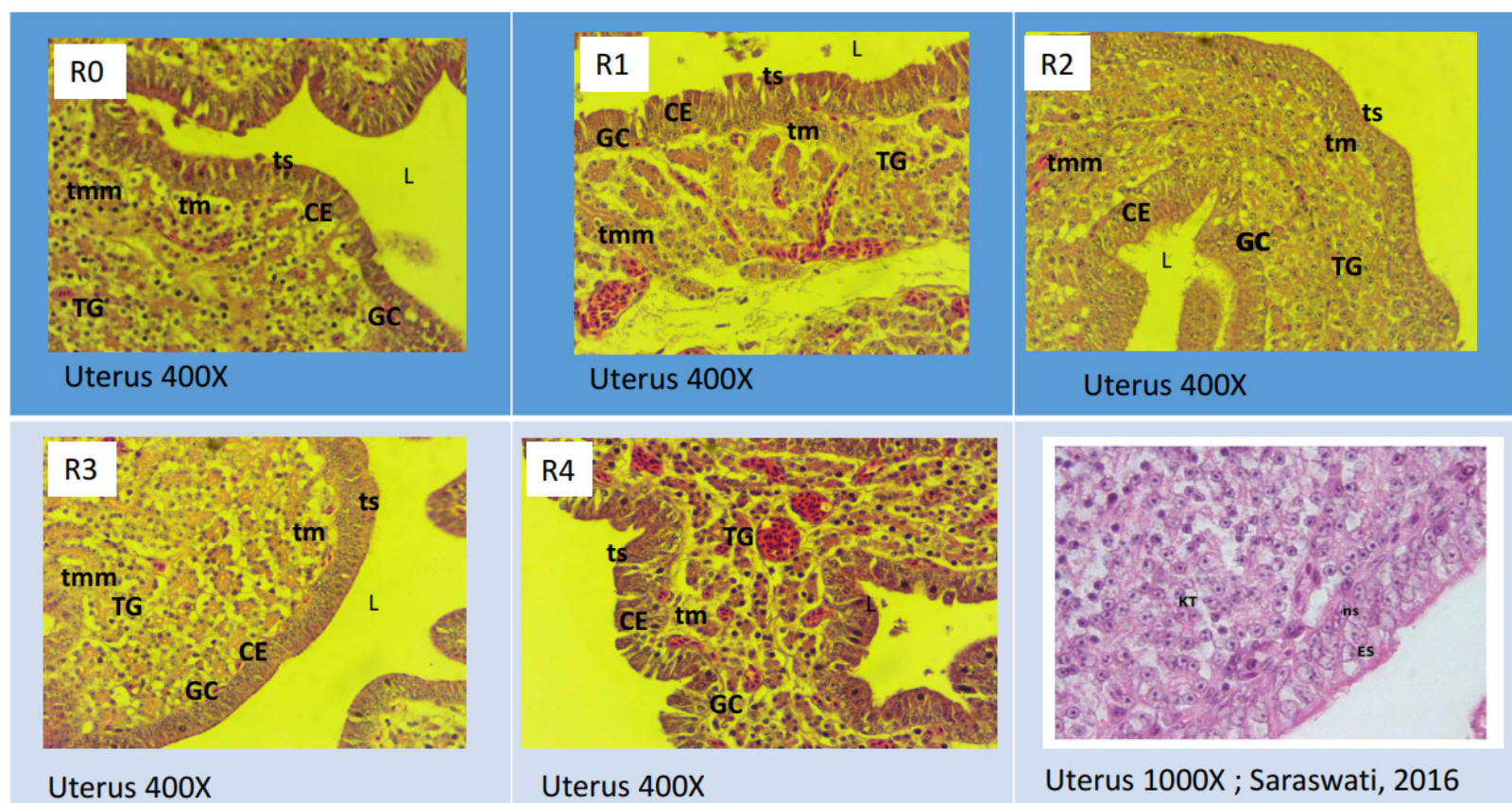

Uterus $400 \mathrm{X}$

Uterus 400X

Uterus 1000X ; Saraswati, 2016

Figure 4. Histology of Magnum in quail fed fermented kangkong seed meal (Bikafer). R0= commercial feed; R1= 0\% Bikafer; R2=7.5\% Bikafer; R3=15\% Bikafer and R4=22.5\% Bikafer. Magnification 40×. L: Lumen; PF: Primary Fold / Primary Fold; SF: Secondary Fold; tm: tunica mucosa; ts: tunica serosa; tmks: tunica muscularis

Jurnal Biodjati 6(1):111-121, May 2021 


\section{JURNAL BIDDJATI}

http://journal.uinsgd.ac.id/index.php/biodjati

\section{ACKNOWLEDGEMENTS}

The authors gratefully thank all colleagues in the department for their help and technical assistance during laboratory analysis. This research received funding from DIKTIS of the Ministry of Religious Affairs. DIKTIS has no role in the design, analysis, or writing of this article.

\section{REFERENCES}

Artoni, S., Carneiro, A. P. M., Giacomini, G., Moraes, V., Araújo, C. S. S. \& Araújo, L. F. (2003). Avaliac, ão macroscópica e morfométrica dooviduto de codornas (Coturnix coturnix japonica) quando alimentadascom diferentes níveis de proteína. Braz. J. Poult. Sci, 3(3), 1-10.

Arum, I., Sumiati, S. \& Abdullah, L. (2019). Pemanfaatan Isoflavon dalam Pucuk Daun Indigofera zollingerian sebagai Sumber Fitoestrogen untuk Meningkatkan Produksi dan Reproduksi Puyuh Petelur. Jurnal Ilmu Produksi dan Teknologi Hasil Peternakan, 5(2), 5660.

Bahr, J. M. \& Johnson, P. A. (1991). Reproduction in poultry. In: Reproduction in Domestic Animal. New York: Academic Press. Inc.

Brionne, A., Nys, Y., Hennequet-Antier, C. \& Gautron, J. (2014). Hen Uterine Gene Expression Profiling during Eggshell Formation Reveals Putative Proteins Involved in the Supply of Minerals or in the Shell Mineralization Process. BMC Genomics, 15(220), 1-17.

Bule, M., Khan, F. \& Niaz, K. (2020). Flavonoids, Recent Advances in Natural Products Analysis. Amsterdam: Elsevier Inc.

Fitzgerald, T. C. (1969). The Coturnix Quail
Anatomy and Histology. Ames Iowa: The Iowa state University press.

Gilbert, A. B., Perry, M. M., Waddington, D., \& Hardie, M. A. (1983). Role of Atresia in Establishing the Follicular Hierarchy in the Ovary of the Domestic hen (Gallus domesticus). J. Reprod. Fertil, 69(1), 221-227.

Glover, A. \& Assinder, S. J. (2006). Acute Exposure of Adult Male Rats to Dietary Phytoestrogen Reduces Fecundity and Alters Epididymal Steroid Hormon Receptor Expression. J. Endocrinol, 189(3), 565-573.

Gongruttananun, N. (2011). Influence of Red Light on Reproductive Performance Eggshell Ultrastructure, and Eye Morphology Inthai-native Hens. Poult. Sci., 90(12), 2855-2863.

Horchow, W. M. (2012). Size of Reproductive Canal Channels in Pullet Phase which are Fed with a Mixture of Seaweed (Gracilaria edulis). Agrinimal, 2(2), 75-80

Laelasari \& Purwadaria, T. (2004). Assessment of the Nutritional Value of Aspergillus niger Mutant Fermentation in the Substrate of Coconut Cake and Palm Kernel Cake. Biodiversitas, 5(2), 48-51.

Majama, Y. B., Mshelia, G. D., Lawal., J. R., Zakariah, M., Charles, A. C., Bwala, D. A., Gazali, A. \& Kachamai, W. A. (2016). Morphometrical and Histological Study of the Female Reproductive Tract of the Japanese Quail (Coturnix coturnix japonica) in Jos, Plateau State, Nigeria. Direct Res. J. Agric. Food. Sci, 4(6), 116-121.

McDaniel, G. R., Brake, J., Experiment, A., Eckman, M. K., Alabama, T. \& Flanders, C. (1981). Factors Affecting Broiler Breeder Performance. Poultry 


\section{JURNAL BIDDJATI}

http://journal.uinsgd.ac.id/index.php/biodjati

Science, 60(2), 1792-1797.

Moreng, R. E. \& Avens, J. (1985). Poultry Science and Production. Virginia: Reston Publishing Company Inc.

Panjaitan, I., Sofiana, A. \& Priabudiman, Y. (2012). Cricket Flour Supplementation as a Source of Protein has an Influence on the Performance of Quails (Coturnix coturnix japonica). Jurnal Ilmiah Ilmu-Ilmu Peternakan, 15(1), 8-14.

Perche, O., Lainé, M., Pageaux, J., Laugier, C. \& Sandoz, D. (1989). Modification of Cell Evagination and Cell Differentiation in Quail Oviduct Hyperstimulated by Progesterone. Biology of the Cell, 67(2), 123-134.

Purwoko, T., Gandjar, I. \& Pawiroharsono, S. (2001). Biotransformasi Isoflavon oleh Rhizopus oryzae UICC 524. Biosmart, 3(2), 7-12.

Ravindran. P. N., Babu, K. N \& Sivaraman, K. (2007). Tumeric. The Genus Curcuma. New York: CRC Press London.

Renema, R. A., Robinson, F. E., Oosterhoff, H. H., Feddes, J. J. \& Wilson, J. L.(2001). Effects of Photostimulatory Light Intensity on Ovarian Morphology and Carcass Traits at Sexual Maturity in Modern Andantique Egg-type Pullets. Poult. Sci., 80(1), 47-56.

Robinson, F. E., Renema, R. A., Oosterhoff, H. H., Zuidhof, M. J. \& Wilson, J. L. (2001). Carcass Traits: Ovarian Morphology and Egg Laying Characteristics in Early Versus Late Maturing Strains of Commercial Egg-type Hens. Poult. Sci., 80(1), 37-46

Rose, S. P. (1997). Principles of Poultry Science. London: Harper Adams Aqriculture College.

Saraswati, T. R., Manalu, W., Ekastuti, D. R. \& Kusumorini, N. (2013). Increased Egg Production of Japanese Quail (Cortunix japonica) by Improving Liver Function Through Turmeric Powder Supplementation. International Journal of Poultry Science, 12(10), 601-614.

Saraswati, T. R. (2016). Comparison Description Histology Reproductive Tract Organ of Quail that Supplemented by Turmeric Powder Before Sex Mature Period and Not Supplemented by Turmeric Powder. Buletin Anatomi dan Fisiologi, 1(1), 6-12.

Satyaningtijas, A. S., Maheshwari, H., Achmadi, P., Bustaman, I., Kiranadi, B., Julianto \& Kurnia, M. L. (2016). Reproductive Performance of Pregnant Mice Due to Ethanol Extract Purwoceng (Pimpinella alpina). Jurnal Kedokteran Hewan, 17(1), 51-56.

Sugiharto \& Ranjitka, S. (2019). Recent Advances in Fermented Feeds Towards Improved Broiler Chicken Performance, Gastrointestinal Tract Microecology and Immune Responses: A Review. Animal Nutrition Journal, 5(1), 1-10.

Thakur, P. N. \& Kapadnis, P. J. (2019). Gross Anatomical and Biometrical Studies on Oviduct in Japanese Quail. International Journal of Science, Environment and Technology, 8(1), 79-84.

Vali, N. (2008). The Japanese Quail: A Review. Int. J. Puolt. Sci., 7(9), 925-931.

Wahyu. (2004). Poultry Nutrition Science Fifth Edition. Yogyakarta: Gadjah Mada University Press.

Winarno, F. G. (2013). Pangan Gizi, Teknologi, dan Konsumen. Jakarta: PT Gramedia Pustaka Utama.

Yildiz, F. (2005). Phytoestrogen in Functional Foods. Florida: Taylor and Francis Ltd. 